\title{
Open source w zarządzaniu informacją
}

\section{Wprowadzenie}

$\mathrm{T}^{\mathrm{s}}$ ermin informacja występuje w wielu dziedzinach nauki, trudno go więc jednoznacznie zdefiniować. $W$ aspekcie rozpatrywanego zagadnienia najbardziej trafne wydaje się ujęcie charakteryzujące informację jako dane (fakty uzyskane poprzez obserwację, mierzenie itp.) prezentowane w kontekście, który ma określone znaczenie ${ }^{1}$. Informacja podlega procesom przetwarzania, na podstawie których budowana jest wiedza. Dziś, w świecie nieustannej walki o osiąganie przewagi konkurencyjnej trudno wyobrazić sobie prowadzenie jakiejkolwiek działalności bez posiadania rzetelnej informacji. Dlatego bardzo istotnego znaczenia nabiera zarządzanie informacją. Proces ten definiuje się najczęściej jako zautomatyzowane metody zbierania, przetwarzania, przechowywania i udostępniania informacji w możliwie przystępnej formie ${ }^{2}$. Lawinowy przyrost informacji, będący cechą charakterystyczną rozwijającego się społeczeństwa informacyjnego, sprawia, że zarządzanie informacją staje się tym bardziej istotne. Z pomocą w tym niełatwym zadaniu przychodzi nowoczesna technologia informatyczna w postaci sprzętu komputerowego wraz z oprogramowaniem użytkowym, w tym oprogramowaniem open source.

\footnotetext{
${ }^{1}$ A. Kijewska, Systemy informatyczne w zarządzaniu, Gliwice 2005, s. 11.

2 E. Mirecka, Wyszukiwanie, selekcjonowanie i gromadzenie informacji. Cz. 1. Źródła informacji, wyszukiwanie i selekcjonowanie informacji, Warszawa 2003, s. 11.
} 
Początki oprogramowania o otwartym kodzie źródłowym (ang. open source) związane są z grupą hakerów skupioną wokół wolnego oprogramowania (ang. free software) oraz kilkoma wydarzeniami mającymi miejsce pod koniec lat 90. Open source zaistniało bezpośrednio po manifeście Erica Raymonda The Cathedral and the Bazaar z roku 1997, którego publikacja doprowadziła do rozłamu w zwartych dotychczas szeregach społeczności wolnego oprogramowania ${ }^{3}$.

W lutym 1998 r. w Kalifornii powołano organizację Open Source Initiative, której nadrzędnym celem jest rozpatrywanie i zatwierdzanie zgodności licencji oprogramowania z przyjętą definicją otwartego źródła (ang. Open Source Definition). Nie jest to jedyne działanie tej korporacji non profit, odpowiada ona bowiem również za propagowanie idei oraz rozwój społeczności open source ${ }^{4}$.

Wbrew pozorom, aby daną aplikację zaliczyć do grupy programów o otwartym kodzie źródłowym, nie wystarczy samo udostępnienie kodu źródłowego. Zachowanie zgodności z założeniami open source związane jest m.in. ze spełnieniem następujących kryteriów:

- wolna redystrybucja oprogramowania,

- dostępność kodu źródłowego,

- zachowanie licencji open source w pracach pochodnych,

- brak możliwości zastrzeżenia modyfikacji kodu (z wyjątkiem, kiedy licencja pozwala na dystrybucję poprawek),

- brak dyskryminacji osób i grup osób,

- wolność zastosowania programów do dowolnych celów (także komercyjnych $)^{5}$.

Oprogramowanie o otwartym kodzie źródłowym ma wiele zastosowań. Aplikacje zaprezentowane w niniejszym artykule doskonale sprawdzą się zarówno w zastosowaniach domowych, jak i firmowych. Ze względu na złożoność problemu poniżej dokonano subiektywnego wyboru oprogramowania. Programy o otwartym kodzie źródłowym stosowane do zarządzania informacją zostały pogrupowane tematycznie w działach, które odpowiadają poszczególnym procesom informacyjnym.

${ }^{3}$ History of the OSI [on-line]. Open Source Initiative [dostęp 30 września 2008]. Dostępny w World Wide Web: http://www.opensource.org/history.

${ }_{4}$ About the Open Source [on-line]. Open Source Initiative [dostęp 30 września 2008]. Dostępny w World Wide Web: http://www.opensource.org/about.

${ }_{5}$ The Open Source Definition [on-line]. Open Source Initiative [dostęp 30 września 2008]. Dostępny w World Wide Web: http://www.opensource.org/docs/osd. Pod tym adresem dostępna jest pełna lista kryteriów, które musi spełniać oprogramowanie open source. 


\section{Gromadzenie informacii}

ednym z głównych procesów w zarządzaniu informacją jest gromadzenie. Aplikacje odpowiedzialne za tego rodzaju zadanie to głównie systemy bazodanowe, pośród których istnieje wiele o charakterze open source. Część z nich jest zorientowana typowo na zastosowania sieciowe. Do tej grupy zaliczyć można takie systemy, jak: Firebird, MySQL, PostgreSQL oraz SQLite. Pozostałe zaś przeznaczone są głównie do użytku na jednym stanowisku (np. Base oraz Kexi).

Bazy o charakterze sieciowym dostępne są pod wieloma systemami operacyjnymi, a ich głównym przeznaczeniem jest obsługa zbiorów danych osiągalnych za pomocą witryn WWW. Wskazane jest używanie ich przy dużej zawartości przechowywanej informacji.

Programy Base oraz Kexi są projektami będącymi konkurencją dla Microsoft Access. W przypadku tych programów można mówić o dostępie do wielu formatów baz danych (MySQL, dBase oraz Microsoft Access). Dostępne są także ich implementacje na różne platformy sprzętowe. Jednakże ze względu na swoją niewielką wydajność powyższe pogramy zalecane są małym i średnim firmom, gdzie obciążenie systemu bazy danych nie należy do największych.

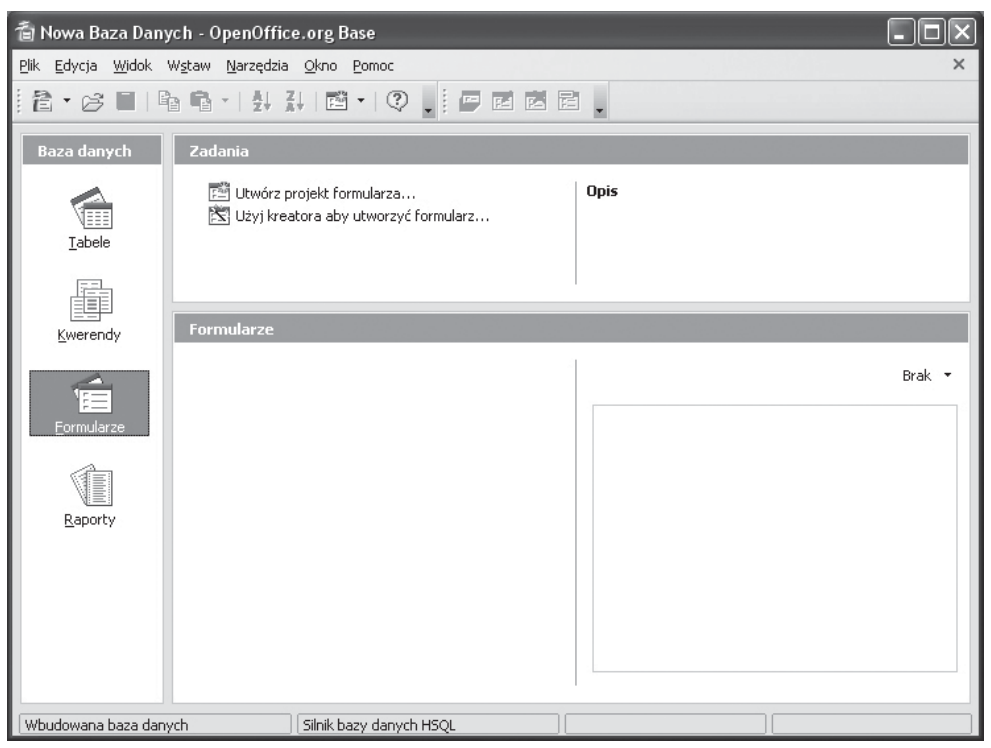

Rysunek 1. Wygląd okna tworzenia nowej bazy danych w programie Base

Źródło: opracowanie własne. 


\section{Przetwarzanie informaci}

7 gromadzone informacje $w$ wielu przypadkach nie są dostatecznie Lprzygotowane do końcowego rozpowszechniania. Udostępnienie informacji w przystępnej i przyjaźnie wyglądającej formie często związane jest z wykorzystaniem języków formatowania tekstu oraz języków programowania.

Gdy mechanizmy dostarczone wraz z oryginalną aplikacją okazują się niewystarczające, często pojawia się potrzeba ich rozbudowywania za pomocą własnoręcznie napisanego programu, a to wymaga specjalistycznej wiedzy programisty. Zastosowania tego rodzaju są niezbędne przy obsłudze niestandardowych aplikacji bazodanowych, takich jak np. sklepy internetowe. Do skryptowych języków programowania z grupy open source najczęściej wykorzystywanych do generowania dynamicznych stron WWW, współpracujących z systemami baz danych, plikami tekstowymi oraz strukturami XML, należą Python i PHP.

\section{Zarzq̨dzanie informacją osobistą}

rupa programów odnosząca się do zarządzania informacją osobistą zyskuje obecnie wielką popularność i stanowi poważną konkurencję dla tradycyjnych form zapisu - drukowanych notatników, kalendarzy i organizerów. Składa się na to wiele czynników, wśród których najistotniejszym jest ciągle powiększające się grono użytkowników urządzeń przenośnych. Programy do elektronicznego zarządzania informacją osobistą posiadają kilka właściwości deklasujących tradycyjne formy zapisu, jak np. niemal nieograniczone miejsce na dokonywane wpisy czy też możliwość dostosowania wyglądu i funkcjonalności interfejsu programu do własnych potrzeb.

Najbardziej znany program do zarządzania informacją osobistą o charakterze open source to Mozilla Sunbird. Jego zadania związane są z organizacją i zarządzaniem czasem. Aplikacja ta jest wygodna i ma przejrzyste menu. Umożliwia zarządzanie kilkoma kalendarzami, dzięki czemu można osobno organizować czas zarówno w domu i pracy, jak i w szkole. W ramach każdego z rozkładów zajęć można dodawać wydarzenia, które wyświetlane są w głównym oknie aplikacji, oraz zadania - umiejscawiane w pasku po lewej stronie okna. W obu przypadkach podczas tworzenia 
nowego zdarzenia należy uzupełnić dane odnoszące się do jego nazwy i miejsca, czasu trwania oraz adresu strony WWW, która zawiera informację o nim. Dodawane elementy mogą być oznaczone jako cykliczne. Ponadto w programie można wybrać funkcję przypomnienia i określić priorytet zadania, a także obecny procent jego wykonania. Opcja wydarzeń umożliwia dodawanie osób z nimi związanych. Istotną zaletą programu Sunbird są dodatki, które po zainstalowaniu znacznie poszerzają możliwości kalendarza. Kalendarz można wyposażyć np. w jego hebrajski odpowiednik, menedżer dni urodzin oraz element wyświetlający datę z dowolnej strefy czasowej ${ }^{6}$.

W przypadku, gdy użytkownik nie chce skorzystać z osobnej aplikacji do zarządzania informacją osobistą, może zastosować wersję przeznaczoną dla klienta poczty elektronicznej - Mozilla Thunderbird. Dodatek Lightning cechuje się podobną funkcjonalnością jak Mozilla Sunbird. Dodatkowo istnieje tu możliwość wysyłania i otrzymywania zaproszeń związanych ze spotkaniami i zdarzeniami.

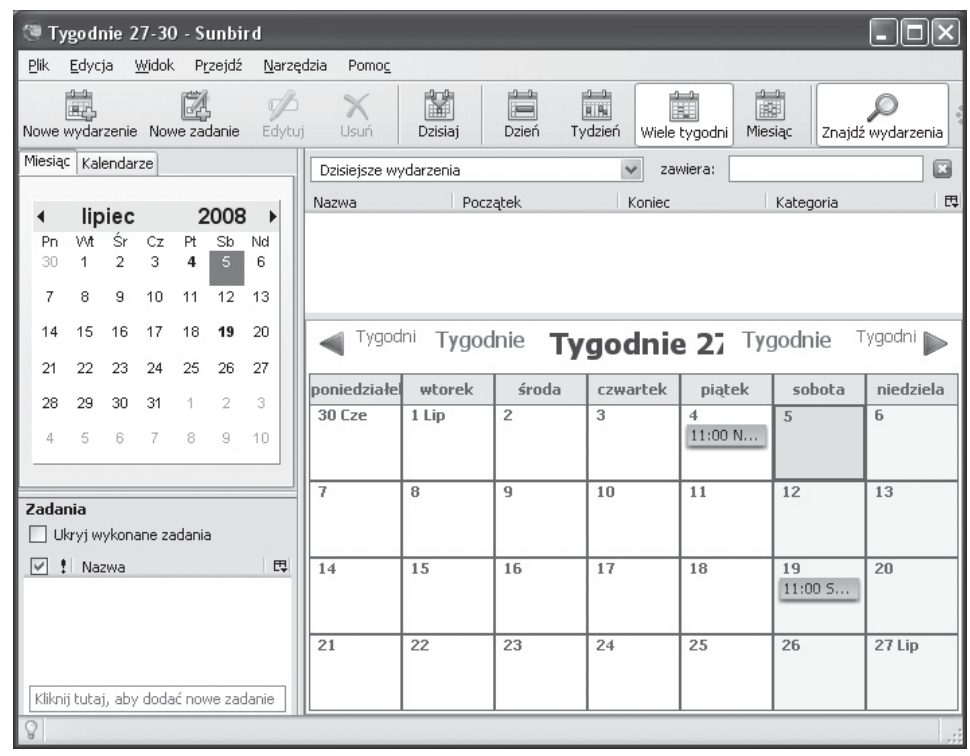

Rysunek 2. Wygląd okna kalendarza z notatkami osobistymi w programie Mozilla Sunbird

Źródło: opracowanie własne.

${ }^{6}$ Sunbird - Dodatki [on-line]. Mozilla Corporation's [dostęp 30 września 2008]. Dostępny w World Wide Web: http://addons.mozilla.org/pl/sunbird/. 


\section{Bezpieczeństwo informacii}

Kolejnym aspektem związanym z zarządzaniem informacją jest bezpieNczeństwo. Ponieważ w wielu przypadkach zasoby danych mają charakter poufny, przypadkowy dostęp do nich przez osoby niepowołane jest niewskazany. W zależności od przeznaczenia programy zabezpieczające informacje mogą mieć różny zasięg. Mogą one m.in. zapewniać kompleksową ochronę dla całego systemu (np. zapory ogniowe czy programy antywirusowe) i chronić w ten sposób zarówno informacje poufne, jak i niemające dla użytkownika większej wartości. Do zabezpieczania zasobów można użyć także programów szyfrujących oraz zarządzających hasłami, które umożliwiają wybór poziomu ochrony strategicznych informacji.

Przykładem programu o otwartym kodzie źródłowym, który zabezpiecza dane, jest Eraser. Program odpowiada za nieodwracalne usuwanie plików i folderów z najbardziej popularnych nośników informacji ${ }^{7}$, co jest szczególnie istotne w przypadku, gdy nie chcemy, aby osoba, która korzysta z tego samego komputera, miała możliwość odzyskania poufnych plików. Aplikacja ta działa poprawnie dla danych zapisanych na dyskach twardych, dyskietkach oraz nośnikach optycznych wielokrotnego zapisu. Dopuszczalna jest także możliwość ustalenia cyklicznego harmonogramu kasowania informacji.

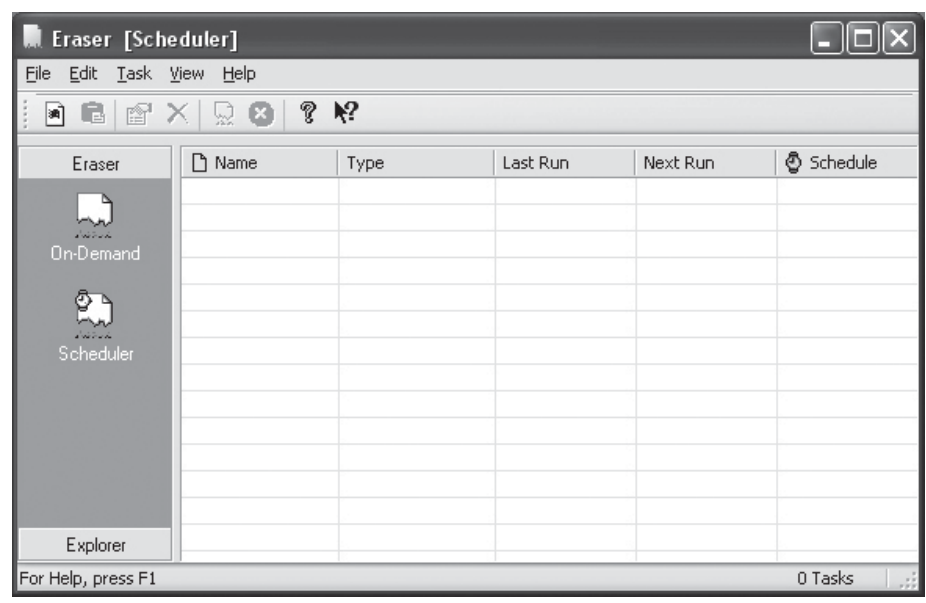

Rysunek 3. Wygląd programu do szyfrowania danych Eraser Źródło: opracowanie własne.

${ }^{7}$ Eraser [on-line]. Heidi Computers Ltd. [dostęp 30 września 2008]. Dostępny w World Wide Web: http://www.heidi.ie/node/6. 
W celu zabezpieczenia i autoryzacji dostępu w wielu systemach informatycznych stosowane są hasła. Zadaniem kolejnego programu open sour$c e$, o nazwie KeePass, jest zarządzanie hasłami. Nieautoryzowany dostęp do witryn bankowości internetowej, poczty elektronicznej czy kont użytkowników systemu operacyjnego może spowodować nieodwracalne straty. Dlatego hasła muszą być skomplikowane i różne dla każdej z wymienionych usług. Specjalnością tego programu jest zapamiętywanie większej liczby różnych haseł. Baza programu KeePass, w której przechowywane są hasła, zabezpieczona jest najlepszymi obecnie znanymi algorytmami AES i Twofish $^{8}$, a dostęp do niej uzyskiwany jest za pomocą hasła bądź pliku klucza.

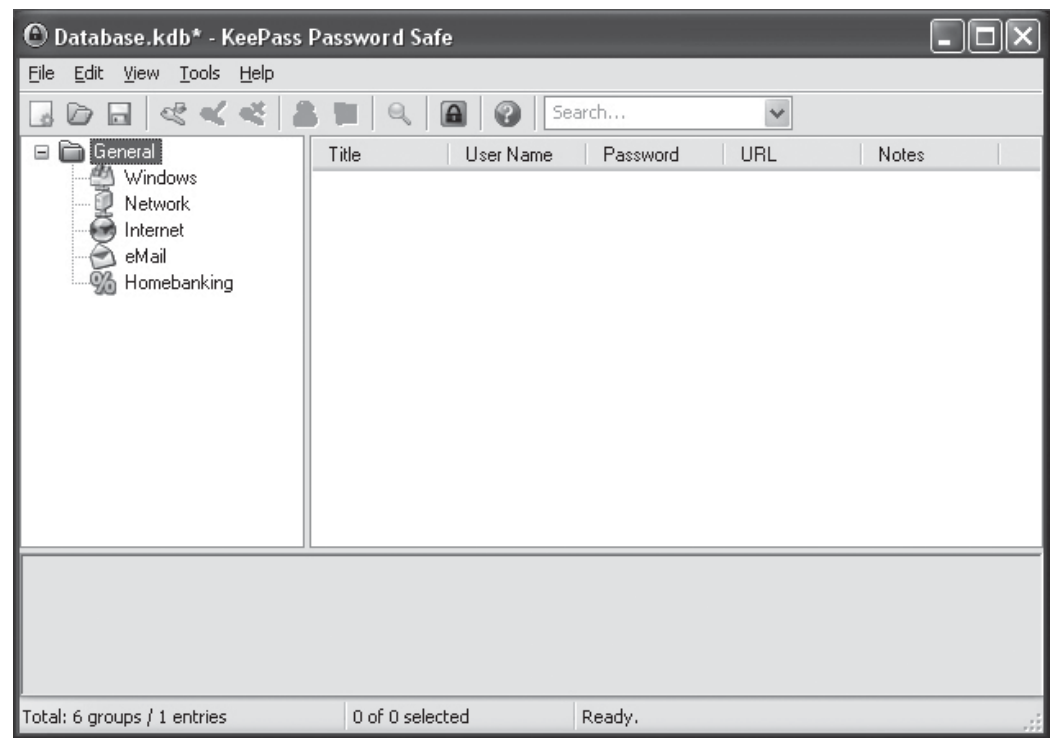

Rysunek 4. Wygląd okna programu do zarządzania hasłami KeePass Źródło: opracowanie własne.

\section{Udostępnianie informacii}

$\mathrm{O}$ tatecznym procesem wieńczącym tworzenie, gromadzenie i przetwarzanie informacji jest jej prezentacja i udostępnienie. Najczęściej informacje publikowane są w Internecie, a większość z nich jest udostępniana za pomocą usługi WWW, którą z kolei realizują serwery WWW.

${ }^{8}$ KeePass Password Safe [on-line]. Dominik Reichl's homepage [dostęp 30 września 2008]. Dostępny w World Wide Web: http://keepass.info/index.html. 
Najbardziej popularnym programem tego typu jest Apache. Nie jest on jedyną aplikacją open source z tej kategorii. Warty wspomnienia jest także program Xitami, który pomimo dość archaicznego jak dla informatyki wieku pozostaje ciągle użytecznym narzędziem.

\section{Podsumowanie}

Programowanie open source jest jednym z ciekawszych rozwiązań przydatnych w procesach zarządzania informacją. Nie odbiega ono funkcjonalnością od swoich odpowiedników o zamkniętym kodzie źródłowym. Choć w kilku przypadkach dyskomfortem może okazać się brak polskiej wersji językowej, to niewątpliwą zaletą tego typu programów jest możliwość ich weryfikacji przez tysiące innych programistów. Tym samym trudniej jest przeoczyć usterkę i niemożliwe staje się wprowadzenie szkodliwego kodu źródłowego. Dzięki temu bezpieczeństwo przechowywanej, przetwarzanej i udostępnianej informacji jest zdecydowanie większe. Oprogramowanie o otwartym kodzie źródłowym warto polecić zarówno do zastosowań biznesowych, jak i domowych. Minimalizacja kosztów użytkownika (omówione programy są dostępne bezpłatnie), nowe sprzężenia między usługodawcami a ich klientami czy unikanie dublowania prac nad rozwiązaniem jednego problemu to oczywiste zalety tego typu rozwiązań, pozwalające optymistycznie patrzeć na ich rozwój.

\section{Open source in the management of information Abstract}

The article concerns using open source software in libraries. It is one of the most popular type of applications introduced in many fields. The author describes the most popular free of charge applications which can be introduced in libraries. The new technological solutions improve and automate these kinds of services like searching, creating, processing and delivering of information. This report shows the practices based on open source applications in reference to the management of information. 